\title{
SUPERVISION OF KPPU ON THE ACTION OF MERGERS DONE BY MINING COMPANIES
}

\author{
${ }^{1}$ Preeti Kartika Putri, ${ }^{2}$ Paramita Prananingtyas \\ ${ }^{1}$ Faculty of Law, Universitas Diponegoro, Semarang, preetikartika79@gmail.com \\ ${ }^{2}$ Faculty of Law, Universitas Diponegoro, Semarang, pptyas@yahoo.com
}

\begin{abstract}
Mining companies conduct mergers to ensure and strengthen their position in their relevant market. Mining company mergers that aren't supervised can result in monopoly and unfair business practices. The issue discussed is the supervision of mergers for mining companies by KPPU. This is a normative juridical research through a statutory and conceptual approach. The result indicates that mining companies are subject to legal provisions of limited liability company and competition law.There is no regulations regarding mergers in Indonesian mining law. Supervision of said mergers by KPPU can be carried out by voluntary consultation or by obligatory post merger notification. The scope of KPPU's supervision also includes mining companies' compliances in case of notification. Delay of such notification will be examined by KPPU and subsequently fined if proven to have committed violation. However, post merger notification is only adopted by only a few countries for it is considered no longer guarantee legal certainty.
\end{abstract}

Keywords: KPPU’ Supervision; Merger; Mining Companies

\section{Introduction}

As one of the most essential aspect of a nation, economy must be aligned with the current law. Law and economy are two different elements of social life that are somehow interrelated and interdependent. The law functions to regulate economic acts so that the rights and interests of each economic actor can be protected and fulfilled. ${ }^{1}$ Law and its functions are needed to boost economic development by regulating the allocation of limited economic resources in order to meet the needs of the community fairly and equitably. ${ }^{2}$ In another words, law plays an important role related to the creation of economic efficiency to realize social welfare. ${ }^{3}$ Competition in a business is conditio sine qua non or an absolute requirement for the implementation of a market economy. Competing in business is a natural thing, because along with competition, the economic activity becomes lively and dynamic. ${ }^{4}$

Producers, manufacturers, and sellers are all trying to survive in the world of trade by doing every possible measures best for the sake of their interests. One of the most widely used strategies by the companies is mergers. Related to the competition law, Law 5/1999 defines

\footnotetext{
Hermansyah, Pokok - Pokok Hukum Persaingan Usaha Di Indonesia (Jakarta: Prenada Media Group, 2009). Ibid.

3 Susanti Adi Nugroho, Hukum Persaingan Usaha Di Indonesiadalam Teori Dan Praktek Serta Penerapan Hukumnya (Jakarta: Prenada Media Group, 2018).

4 Ibid.
}

108 
merger as an act that results in the creation of a concentration of control from several business actors who were previously independent to one business actor or a business group; or the transfer of control from one business actor to another business actors that were previously each independent - thus creating a concentration of control or market concentration. ${ }^{5}$ Mergers are regulated within the competition law because it will affect the dynamic of the relevant market and affecting the competition itself. Merger is actually beneficial for all parties involved, for merger can provide leverage for business actors in providing production output to consumers, since the competition in the market is getting increasingly difficult. A merger is carried out solely to meet the interests of the company will easily turns into unfair business competition practice. Merger is an anti-competitive action, in the event that post merger, the business actor has the ability to determine prices and has a dominant position in the relevant market. ${ }^{6}$

Mining companies are among dozens of companies who sees merger as a way out to expand the company and explore new possibilities. It is no secret that mining is a highly profitable industry, thus attracting a lot of interests from businessmen. Mining companies all over the world including here in Indonesia are using merger to enrich their own raw materials and resources, because while natural resources are dwindling, the global demand are increasing. Mergers among mining companies are intended to secure and control the mining supplies. However, the government also has the responsibility to ensure such merger does not result in unlawful domination nor monopoly that would only end up in hurting both the competition and the market. This paper will discuss further about the government's supervision through the Business Competition Supervisory Commission (KPPU) on the action of mergers done by mining companies.

\section{Methods}

This research uses a normative juridical method, that is a research process to find legal rules, legal principles, and legal doctrines. The approaches used in this research are statutory approach and conceptual approach. All approaches are conducted to dig into the Business Competition Supervisory Commission (KPPU) supervisory practices regarding mergers control for mining companies in accordance with Law 5/1999, with several comparisons from other countries. Results are explained in an analytical descriptive manner, using qualitative data

$\begin{array}{ll}5 & \text { Ibid. } \\ 6 & \text { Ibid. }\end{array}$ 
collected from law, regulations, and journals from previous researches. The obtained data will be analyzed qualitatively to draw a deductive inference.

\section{Results and Discussion}

Company law regulates mergers in Law 40/2007 on Limited Liability Company and Government Regulation 27/1998 on Merger, Consolidation, and Acquisition of Limited Liability Company. In the term of company law, Law 40/2007 is the main legal instrument, and the merger arrangements can be found in Chapter VIII Article 122 - 137. The government regulation serves as a complementary legal instrument to the main, giving more detailed points. There are no specific articles regulating mining companies merger, for all articles only uses the term company. It is safe to say that when mining companies decided to conduct a merger, then they must comply to the Limited Liability Company law as what every other company does, because there are no distinction among them.

Talking about mining companies, we need to take a look at the regulations from the mining law itself. There are two main mining laws here in Indonesia, Law 22/2010 on Oil and Gas, and Law 4/2009 on Minerals and Coal. Both laws require implementing regulations. The implementing regulation for Law 22/2010 on Oil and Gas is in the form of government regulations covering all matters related to oil and gas business activities. Whereas the implementing regulation for Law 4/2009 on Mineral and Coal is also in the form of government regulations covering al matters related to minerals and coal business activities. The Minister of Energy and Mineral Resources also issued regulations to regulate all matters related to mining in the form of regulations of the Minister of Energy and Mineral Resources. Companies' participation in mining activities must be based on a permit to carry out mining business. A company is allowed to have one or several permits to carry out a mining business related to the specifications of its line of business.

The ministerial regulations are drafted so that the company continues to improve the efficiency and effectiveness of resource utilization. The form of cooperation regulated in the ministerial regulations is through the signing of a cooperation agreement or through the establishment of a joint venture. There is no articles that mentions or regulates the merger of mining companies, either implicitly or explicitly. Therefore, the regulation regarding mergers for mining companies refers to the law of limited liability companies. Mining companies that will 
conduct a merger must meet the requirements and follow the same steps as any limited liability company in general. Table of merger regulations is shown as below.

Table 1.

Merger Regulations

\begin{tabular}{|c|c|c|c|}
\hline \multirow[b]{2}{*}{ Regulated Object } & \multicolumn{2}{|c|}{ Limited Liability Company Law } & \multirow[b]{2}{*}{ Mining Lay } \\
\hline & Law 40/2007 & $\begin{array}{c}\text { Government Regulation } \\
27 / 1998 \\
\end{array}$ & \\
\hline Merger Requirements & $\begin{array}{l}\text { Article } 126 \text { paragraph (1), } \\
\text { (2), (3);Article } 123 \\
\text { paragraph (3) and (4). }\end{array}$ & $\begin{array}{l}\text { Article 4, 5, and } 6 \text { paragraph } \\
\text { (1) }\end{array}$ & None \\
\hline Draft of Merger Plan & $\begin{array}{l}\text { Article } 123 \text { paragraph (1), } \\
(2) \text {, and (3) }\end{array}$ & Article $7,8,9,10$, and 11 & None \\
\hline Merger Announcement & $\begin{array}{l}\text { Article } 127 \text { paragraph (2), } \\
(3),(4),(6) \text {, and (7) }\end{array}$ & $\begin{array}{l}\text { Article } 12 \text { and } 33 \text { paragraph } \\
\text { (1) }\end{array}$ & None \\
\hline $\begin{array}{l}\text { Legitimation of Merger } \\
\text { Decision }\end{array}$ & Article 127 paragraph (1) & Article 13 & None \\
\hline Deed of Merger & $\begin{array}{l}\text { Article } 128 \text { paragraph (1); } \\
\text { Article } 129 \text { paragraph (1) } \\
\text { and (2) }\end{array}$ & Article 19 paragraph (1) & None \\
\hline $\begin{array}{l}\text { Announcement of the Result } \\
\text { of the Merger }\end{array}$ & Article 133 paragraph (1) & Article 34 & None \\
\hline $\begin{array}{l}\text { Changes to the Articles of } \\
\text { Association }\end{array}$ & $\begin{array}{l}\text { Article } 129 \text { paragraph (1) } \\
\text { and (2) }\end{array}$ & Article $14,15,16$, and 17 & None \\
\hline Effective Date of Merger & Article 133 paragraph (1) & Article 18 & None \\
\hline $\begin{array}{l}\text { Legal Consequences of } \\
\text { Merger }\end{array}$ & Article 122 & Article 3 and 19 & None \\
\hline
\end{tabular}

Indonesia has a clear and detailed arrangements regarding legal provisions and institutions related to the implementation of merger. ${ }^{7}$ Indonesian competition law does not specifically regulate mergers for mining companies. Mining companies who wishes to merge are subject to competition law that apply to all limited liability companies. General arrangements regarding mergers are accommodated in Law 5/1999 on Prohibition of Monopolistic Practices and Unfair Business Competition. Merger is very risky to stimulate the surviving company to reach a

7 I Nyoman Wisnu and Ahmad M. Ramli Wardhana, "Harmonisasi Hukum Perusahaan Di ASEAN Sebagai Faktor Fundamental Dalam Implementasi Kegiatan Merger and Acquisition (M\&As)," Padjajaran Jurnal Ilmu Hukum 2, no. 2 (2015): 329. 
dominant position that is prohibited to a certain extent by applicable laws and regulations. ${ }^{8}$ Therefore, the articles governing mergers are contained in Chapter $\mathrm{V}$ regarding Dominant Position, namely in articles 28 and 29. Further elaboration of the two articles can be found in Government Regulation 57/2010 on Merger of Business Entities, or Consolidation of Business Entities and Takeover of Company Shares that Can Lead to Unfair Business Competition. Government Regulation 57/2010 explains the provisions for mergers thresholds as well as the procedure for merger notification.

Regulation related to merger notification adopted worldwide are divided into pre merger notification (ex ante regulation) and post merger notification (ex post regulation). In addition to that, several countries don't oblige the merging companies to notify their mergers, rather doing it voluntarily, whereas there are few countries that set certain threshold for compulsory merger notification. ${ }^{9}$ Indonesian competition law supervises mergers through compulsory notification by companies after a merger occurs. ${ }^{10}$ Notification of a merger is regulated in Regulation of the Business Competition Supervisory Commission 2/2013 on the Third Amendment to Regulation of the Business Competition Supervisory Commission 13/2010 on Guidelines for Implementing Mergers or Consolidation of Business Entities and Acquisition of Company Shares which Can Result in Monopolistic Practices and Unfair Business Competition.

Supervision of the merger serves as a preventative regulatory tool. This supervision action helps the country to take preventive steps towards various merger transactions which will most likely have a negative impact on competition, thereby reducing the need to regulate markets laden with anticompetitive practices. Supervision of mergers can prevent companies from establishing oligopoly power in certain sectors that harm consumers' interests. ${ }^{11}$ According to the competition law perspective, mergers must be monitored for several reasons. First, a merger can have an effect on competitive conditions in the relevant market. This happens because the joint companies will form a larger market share, thus impacting competition. Second, mergers can cause or even strengthen market power by increasing concentration in the relevant market. The increase in market power can increase a company's ability to abuse its power to inhibit

\footnotetext{
8 Nugroho, Hukum Persaingan Usaha Di Indonesiadalam Teori Dan Praktek Serta Penerapan Hukumnya.

9 Jian and Liyang Hou Li, "The Compulsory Notification Mechanism under Merger Control in China: Evaluation and Reform," SSRN Electronic Journal 630, no. 1 (2019): 1.

10 Daren and Elsa Chen Shiau, "ASEAN Developments in Merger Control," Journal of European Competition Law \& Practice 5, no. 3 (2014): 150.

11 Ibid.
}

112 
competition so that it harms consumers. Mergers can be a tool for companies to get rid of their competitors and / or to reduce competition. ${ }^{12}$

The enactment of Law No. 5 of 1999 as a basis for competition policy is followed by the establishment of the Business Competition Supervisory Commission (KPPU) to ensure and supervise compliance with the provisions in the law. KPPU is not a law enforcement agency, but an institution that has a complex task in supervising unfair business competition practices by business actors. ${ }^{13}$ KPPU has two main tasks in carrying out supervision, namely, first, formulating and implementing regulations, examining and investigating and adjudicating parties who violate the law; and secondly, provide advice and considerations on government policies relating to monopolistic practices and unfair business competition. KPPU has the authority to study and approve merger transactions as well as to give permission or declare endorsement if the transaction has no potential for monopoly. ${ }^{14}$

KPPU has the authority to prevent merger transactions that can result in monopoly and unfair business competition. This can be done through an evaluation of the analysis report submitted by the company prior to the merger transaction, as stipulated in Regulation of the Business Competition Supervisory Commission 11/2010 on Consultation on the Merger or Consolidation of Business Entities and the Takeover of Company Shares. Although article 29 paragraph (1) requires merger reporting obligations that have been carried out, but it does not rule out the possibility for preventive examinations carried out on an initiative by KPPU. The nature of consultation is voluntary, so there is no obligation for business actors to conduct consultations. The evaluation conducted by KPPU in the consultation process is an initial assessment.

The results of the consultation assessment are given in the form of a written opinion regarding the presence or absence of alleged monopolistic practices and / or unfair business competition. The results of the consultation assessment do not constitute approval or rejection of the merger plan. The assessment given for the merger consultation does not nullify the KPPU's authority to conduct an assessment after the merger transaction. However, in order to avoid repeating the assessment of the same merger through consultation and notification, KPPU is

12 Nugroho, Hukum Persaingan Usaha Di Indonesiadalam Teori Dan Praktek Serta Penerapan Hukumnya.

13 Rai ; Hazar Kusmayanti and Anita Afriana Mantili, "Problematika Penegakan Hukum Persaingan Usaha Di Indonesia Dalam Rangka Menciptakan Kepastian Hukum," Padjajaran Jurnal Ilmu Hukum 3, no. 1 (2016): 121.

14 Nugroho, Hukum Persaingan Usaha Di Indonesiadalam Teori Dan Praktek Serta Penerapan Hukumnya. 
committed to only conducting a one-time assessment of the merger event as long as there is no material change to the data submitted by business actors at the time of notification.

Based on the provisions of article 29 of Law 5/1999 jo. Article 5 Government Regulation $57 / 2010$, the regulated merger supervision is conducted after the merger is carried out (post evaluation). The business actor is obliged to make a merger notification to KPPU in terms of meeting the provisions of certain asset value limits and / or sales values. The limitations are called thresholds, and have become the determining factors to decide whether or not a merger notification report is required. Establishing a suitable threshold is a very challenging thing to do, because it has to grant legal certainties while filter out the sufficient number of mergers. Setting a very high threshold can result in forsaking mergers with anti - competitive harms. While setting a very low threshold can burden the authorities with a workload of notifications to assess. $^{15}$

The calculated asset value and / or sales value is the value of assets and / or sales value of all business groups of the company. This is because economically, the asset value of a subsidiary is the asset value of the parent company. The guideline regarding merger notification is governed in Regulation of the Business Competition Supervisory Commission 2/2013. To fulfill the provisions of Article 29 of Law 5/1999, business actors that have consulted their merger plans still have the obligation to notify the commission in accordance with the provisions of Article 5 paragraph (1) Government Regulation 57/2010. KPPU does not reassess business actors who have conducted merger consultations. Business actors who do not conduct merger consultations will receive an assessment from KPPU once the merger is legally effective.

KPPU conducts monitoring in order to obtain information regarding merger legal actions that are alleged to have fulfilled the requirements but were not notified to KPPU. Monitoring is included in the Monitoring Results Report to identify the delay in merger notification. KPPU reports the late notification in accordance with Article 4 Paragraph (2) of the Regulation of the Business Competition Supervisory Commission 4/2012 on Guidelines for the Imposition of Fines for Late Notification of Merger or Consolidation of Business Entities and Takeover of Company Shares. Article 36 jo. Article 47 Law 5/1999 gives KPPU the authority to impose administrative actions on violations of the law, one of which is through the imposition of fines. Article 6 Government Regulation 57/2010 stipulates that KPPU is authorized to impose sanctions in the form of administrative fines for business entities that are late in notifying

15 Li, "The Compulsory Notification Mechanism under Merger Control in China: Evaluation and Reform." 
mergers. The authority of the KPPU to impose fines for late notification of the merger was reaffirmed in the provisions of article 12 of the Regulation of the Business Competition Supervisory Commission 4/2012.

Mining companies that will conduct a merger with the result of the asset value and / or sales value exceeding a certain amount can consult orally or in writing to the Commission KPPU can evaluate the merger plan. The assessment is an initial assessment, and if necessary a comprehensive assessment can be made to be concluded as an opinion. Based on information from the official website of the Business Competition Supervisory Commission, the Commission's opinion on the proposed merger plan can be known. However, because it is voluntary, not many companies consult. Consultation actions on the planned merger from 2010 to 2019 were carried out by 32 companies, of which 14 were mergers between mining companies.

The list of companies that have made post-merger notifications can be seen on the official website of the Business Competition Supervisory Commission. Mining companies have notified the Business Competition Supervisory Commission after the merger. Based on the publication, there was no opinion from the Business Competition Supervisory Commission that states that a mining company merger transaction has alleged monopolistic practices and / or unfair business competition.

Table 2.

Notification of Mining Companies Mergers

\begin{tabular}{cccccc}
\hline & Number of Notifying Companies & \multicolumn{3}{c}{ Opinion on the Mining Companies Merger } \\
Notifications
\end{tabular}




\begin{tabular}{llllll}
\hline 2017 & 90 & 10 & 7 & 1 & 2 \\
2018 & 74 & 15 & - & - & 15 \\
2019 & 50 & 17 & - & - & 17 \\
\hline Total & $\mathbf{5 3 6}$ & $\mathbf{1 1 0}$ & $\mathbf{7 0}$ & $\mathbf{6}$ & $\mathbf{3 4}$ \\
\hline
\end{tabular}

Based on the table above, mining companies mergers have complied to competition law requirements and regulations. The results of KPPU's analysis so far indicate that the merger of mining companies does not indicate an element of monopolistic practices or unfair business competition, so KPPU has never canceled a merger of a mining company.

The regulation regarding merger notification is contained in Article 6 of Government Regulation 57/2010. The merger must be notified to the Business Supervisory Commission no later than 30 days from the date the merger has been legally effective. Late notification is a violation of Article 6. The Business Competition Supervisory Commission takes action against companies suspected of being late in notifying merger transactions. This can be seen from the website of the Business Competition Supervisory Commission website which lists several decisions related to Alleged Late Notification related to Alleged Violations Article 29 of Law 5/1999 jo. Article 5 Government Regulation 57/2010 regarding Late Notification of Share Acquisition. The Business Competition Supervisory Commission follows up on these violations, including violations committed by mining companies. Alleged delay in merger notification that has been examined by the Business Competition Supervisory Commission since 2010 reached 16 cases, of which four were mining companies.

The four companies are PT Tiara Marga Trakindo, PT Darma Henwa Tbk, PT Bumi Kencana Eka Sejahtera, and LG International Corp. PT Tiara Marga Trakindo and PT Darma Henwa Tbk were each given a fine by KPPU due to the late notification of the merger transaction. PT Tiara Marga Trakindo was proven to be late in notifying the transaction for 41 working days, because the acquisition of PT HD Finance Tbk shares was legally effective on March 11, 2013. The notification must be made no later than 24 April 2013, but PT Tiara Marga Trakindo only made the notice on June 24, 2013. While PT Darma Henwa Tbk was proven to be late in notifying the transaction for 50 working days, because the takeover of the shares of PT Cipta Multi Prima was legally effective on October 6, 2015. Notification must be made no later than November 17, 2015, however, PT Darma Henwa Tbk only made a notice on January 29, 2016. 
PT Tiara Marga Trakindo, serves as the reported, took over the shares of the company PT HD Finance Tbk. The company that is taken over is a public Limited Liability Company, so the taking over process must also be subject to capital market legal regulations. The Reported Party believes that the takeover was effective on May 27, 2013, after it controlled 51\% of PT HD Finance Tbk's shares. Whereas the Business Competition Supervisory Commission believes that the takeover was effective on March 11, 2013 based on a letter submitted reported to the Financial Services Authority regarding the acquisition of PT HD Finance Tbk shares by $45 \%$. According to the Business Competition Supervisory Commission, ownership of $45 \%$ can be referred to as a form of control, whereas the reported party believes that it is referred to as control if the share ownership is more or equal to 51\%. The Commission Council fined PT Tiara Marga Trakindo through case number 07 / KPPU - M / 2014.

LG International Corp. was late in notifying PT Binsar Natorang Energi's takeover of shares. LG International Corp. acquired PT Binsar Natorang Energi's 51\% stake, legally effective since June 12, 2014 based on the Letter of the Director General of Legal and General Administration of the Ministry of Law and Human Rights. However, the new notification was made on August 27, 2014. The delay in notification of the transaction was motivated by the reported confidence that the acquisition of PT Binsar Natorang Energi did not meet the value limit (treshold) required by Indonesian law. The Commission Council passed a fine to the reported party in Case Decision Number 16 / KPPU-M / 2015.

PT Darma Henwa Tbk was fined by KPPU through case verdict number 09 / KPPU - M / 2017 related to delay in notification of merger. PT Darma Henwa Tbk acquired the shares of the company PT Cipta Multi Prima Tbk. The delay in notification of a merger transaction is due to the reported belief that a takeover transaction is not required to be notified because it occurs between affiliated companies. Affiliation occurs because both companies have the same director. However, KPPU does not agree and states that the transaction was not conducted between affiliated companies. Therefore, the reported party still has the obligation to make a merger notification.

The fourth mining company examined by the Business Competition Supervisory Commission related to the late notification of the acquisition of shares was PT Bumi Kencana Eka Sejahtera, which took over the shares of PT Andalan Satria Lestari. The takeover of shares was carried out in two stages, where both stages were effective respectively on February 27, 
2012 and April 27, 2012. The first stage acquisition took over $99.83 \%$ new shares and the second stage acquisition took over PT Andalan Satria Lestari's shares $99.99 \%$

The notification was only carried out after the second phase of the takeover of shares, namely on May 25, 2012, because the acquisition of the first shares did not result in a change in control of the target company. This is the point of misunderstanding between PT Bumi Kencana Eka Sejahtera as reported with KPPU. Contrary to the reported opinion, the investigating team considered that the reported party had taken over the control of the company PT Andalan Satria Lestari at the time of the first takeover of shares, because it had controlled the majority shares. Therefore, the takeover of the first tranche of shares must be notified.

The takeover of shares must be notified on the legal effective date of the takeover, i.e. the date of notification was received by the minister. The reported party only received notification documents after the second stage of the takeover process. The document received at the time of the first phase of the takeover was a ministerial decree on approval of amendments to the articles of association, related to the increase in authorized capital, not regarding changes in shareholders in PT Andalan Satria Lestari. The Assembly considers that the effective date of acquisition of shares is 30 days since the issuance of the notification document received by the minister on April 27, 2012. Based on this, the Commission Council, through the decision of Case No. 08 / KPPU-M / 2012, stated that PT Bumi Kencana Eka Sejahtera was not late in notifying.

KPPU's supervision of the actions of mergers of mining companies is not only about the assessment of consultations and notices, but also includes the provision of fines for mining companies that are late in notifying. None of the merger cases included in the Business Competition Supervisory Commission indicate that monopolistic practices and / or unfair business competition has occurred, but rather the non-compliance in notifying merger transactions.Such supervision by KPPU does have the potential to be harmful for the merging companies. Fine sanctions for non - compliance violations are somehow bearable, with a major economic loss. However, it would be such an unfortunate event if KPPU did revoke a merger after believing that it leads to monopolistic and unfair business practices, thus violating Law 5/1999. Even though to date there hasn't been any revoked mergers yet, but the damaged that will follow the aftermath will be devastating for the merging parties. Revoke of a merger meaning that the merged or combined companies should be broken down back to its original state, a two separate entities. This kind of merger notification causes legal uncertainty among 
companies who wishes to merge, because the result of the merger notification could either be in their favour or otherwise.

Indonesia enacted its own competition law as an action to fulfill the International Monetary Fund's loan requirement following the monetary crisis back in 1999. Made in a blind haste, the law wasn't satisfactory perfect, yet has never been modified yet. Indonesia is one of the few countries that adopts post merger notification regime, together with Costa Rica and Paraguay. ${ }^{16}$ Costa Rica enacted The Law for the Promotion of Competition and Consumer Protection No. 7492 (the Competition Law) in 1994, earlier than Indonesia. Together with the act, Costa Rica created an institution to enforce the competition law, namely the Competition Promotion Commission (COPROCOM), under the Ministry of Economy. Costa Rica also adopts post merger notification, popularly known as an ex post system since the enactment of their competition law up to 2012. However, the notification system is slightly changed in 2012 with a minor adjustment. While still adopting the previous system, the government added new provisions regarding pre - merger notification.

Steps for filing notification are quite different with the one we have in Indonesia. Here in Indonesia, companies directly notify KPPU following the event of their mergers, and then KPPU will evaluate the notification. Whereas in Costa Rica, mining company wishing to merge must file a notification before SUGEVAL, a superintendency for stock markets who also covers mining industry. This authority agency must then request a technical opinion from COPROCOM before approving and issuing its final decision. Upon 15 days of receiving a request from SUGEVAL, COPROCOM must issue its opinion. Any opinion from COPROCOM is not binding for SUGEVAL. Yet if SUGEVAL does not agree with COPROCOM and not going to act upon its opinion, it must explain its reason. ${ }^{17}$

Under the new notification system, merger notification can be filed before closing the deal or within five calendar days after closing the deal. COPROCOM has 10 days after filing to request additional information, which must be filed by the parties within 10 days. The notification must be made if the merger fulfill Costa Rica Competition Law's certain amount of concentration. Concentration is defined as "any change in control of an entity or of productive assets, as a result of a transaction between two independent entities". Any concentration with

16 Peter; Elsa Sependa and Laura Vlachos Alexiadis, "Merger Control: 'Around the World in 80 Days: Management of the Merger Review Process of Global Deals," Business Law International, 19, no. 3 (2018): 215.

17 Ilene Knable [ed] Gotts, The Merger Control Review, Seventh Edition (London: Law Business Research Ltd, 2016). 
the assets of involved entities together with their parent companies as well as group companies exceeding minimum about US\$ 15 million or when the total revenue generated in Costa Rica during its latest fiscal year of all business entities involved exceeds the minimum US\$ 15 million must be notified. However, there is a Government Decree narrowing the aforementioned threshold, stating that the notification shall be made when there are at least the two involved entities have operations in Costa Rica; as well as provisions to include only productive assets in their last annual financial statement to be considered and also including the value of the said productive assets of all affiliates that operates in Costa Rica within two years prior the proposed merger to be considered by COPROCOM. ${ }^{18}$

Notification can be made by any involved parties. In general, the required documents and paperworks are all the same. However, COPROCOM required the reporting party to also enclose an analysis of any possible anticompetitive effects of the merger, and a proposal to counterbalance such effects. KPPU only asked the merging parties to enclose as much as an analysis of effects of the said merger, whereas the counterbalance proposal only requested upon any indication of substantial lessening competition. CORPORCOM has 30 days to issue its evaluation result, and if it fails to issue the result within the said time frame, then the merger is considered approved. ${ }^{19}$ This kind of provision regarding time frame is quite different with what we have here in Indonesia. KPPU has no time limit to evaluate and issue their opinion. This results in many pending assessments in line, as seen on Table 2 above. Furthermore, if the assessment turns out to disserve the merged company, then the post merger notification system should be revised.

Type of notification adopted by Indonesia has a very complex consequence. It will be very difficult to thwart mergers and acquisitions with fraudulent tendencies. Meanwhile, adopting a pre - notification regime is seen as a way to prevent mergers from causing unfair business competition by many countries, for the antitrust agency will forbid the said merger to be done. Now lets take a look at how the Chilean government controls merger. Chile used to has a voluntary merger notification system, dated back to 1973 until 2017. Having been enforced for so long, the system changed due to heavy criticism from the Organization for Economic Cooperation and Development (OECD). The voluntary system gave option to the merging companies to seek permission from Chilean antitrust agency before the merger takes place. There are two institution to enforce the Chilean antitrust law, namely the Fiscalia Nacional Economica

18 Ibid.

19 Ibid. 
(FNE) and the Tribuna de la Defensa de la Libre Competencia (TDLC). The FNE serves as the Chilean national economic prosecutor, whereas the TDLC serves as an antitrust tribunal. The FNE is an independent agency under the Ministry of the Economy. It is known that the role played by the FNE in enforcing Chilean antitrust law is just as important as the United States' Federal Trade Commission in its own homeland. ${ }^{20}$

Prior to 2017, the Chilean voluntary review system filed by the merging parties to TLDC only serves as a consultative proceeding. However, the FNE and third parties would not be able to challenge any approved mergers. The aforementioned system only gave indeterminate situation for merging companies, because the merging companies were unsure whether or not tu submit their merger for review. Such system did not create incentives for merging companies to notify their mergers prior to their transactions. The notification system was transformed completely in 2017 to a mandatory review with the FNE. Unlike Costa Rica that makes it possible for merger notification to be filed whether prior or after the merger is done, this mandatory review in Chile must be proposed before the merger takes into effect. The threshold are based on how much business the merging parties transact in Chile.

If the aggregate turnover in Chile is greater than USD \$70 million, then the merger is a subject to review. However, if the turnover is over USD \$ 11.3 million, the parties must submit review for preclearance. It safe to say that if the merger does not meet any of those two threshold, then the merging parties do not have to submit the merger review. ${ }^{21}$ The new merger control gives FNE 30 days to either approve the transaction or tell the merging parties that it would like another 90 days to do a more in depth review of the merger. The very important point of this regime is that the parties are not allowed to proceed their merger transactions until the FNE has approved it. ${ }^{22}$ This mandatory review is very beneficial for business in terms of reducing risks, allowing more accurate risk assessment, and reducing legal uncertainty. This is something that must be considered by KPPU to reform the merger notification system.

\section{Conclusions}

Regulations regarding mergers for mining companies are accommodated in limited liability company law and business competition law and both do not specifically regulate mergers for

\footnotetext{
20 Max Samels, Recent Changes to Merger Notification in Chilean Antitrust Law, International Immersion Program Papers, 2018.

21 Ibid.

22 Ibid.
} 
mining companies. Mining law also does not regulate mergers of mining companies. Therefore, government's supervision of mining company mergers can be done through an evaluation of voluntary consultations or mandatory merger notifications by KPPU. The scope of KPPU's supervision also includes compliance of mining companies to make timely merger notifications. None of the merger cases included in the Business Competition Supervisory Commission indicate that monopolistic practices and / or unfair business competition has occurred, but rather the non-compliance in notifying merger transactions.

Indonesia together with Costa Rica and Paraguay are the few countries that adopts post merger notification regime. However, Costa Rica has made amendments and now regulates pre merger notification. Whereas in Chile, heavy criticism from OEDC regarding the voluntary merger notification system has successfully made Chile renew 44 years old system and formulate a new one. Type of notification adopted by Indonesia has a very complex consequence. It will be very difficult to thwart and restore mergers and acquisitions with fraudulent tendencies, thus only create legal uncertainties among merger parties. Not to mention the difficulty to prevent unlawful competition and practices among competing mining companies. It is now without doubt that the government should consider to change the merger notification system, for such change is beneficial for all stakeholders involved.

\section{References}

Alexiadis, Peter; Elsa Sependa and Laura Vlachos. "Merger Control: 'Around the World in 80 Days: Management of the Merger Review Process of Global Deals." Business Law International, 19, no. 3 (2018): 215.

Gotts, Ilene Knable [ed]. The Merger Control Review, Seventh Edition. London: Law Business Research Ltd, 2016.

Hermansyah. Pokok - Pokok Hukum Persaingan Usaha Di Indonesia. Jakarta: Prenada Media Group, 2009.

Li, Jian and Liyang Hou. "The Compulsory Notification Mechanism under Merger Control in China: Evaluation and Reform.” SSRN Electronic Journal 630, no. 1 (2019): 1.

Mantili, Rai; Hazar Kusmayanti and Anita Afriana. "Problematika Penegakan Hukum Persaingan Usaha Di Indonesia Dalam Rangka Menciptakan Kepastian Hukum.” Padjajaran Jurnal Ilmu Hukum 3, no. 1 (2016): 121.

Nugroho, Susanti Adi. Hukum Persaingan Usaha Di Indonesiadalam Teori Dan Praktek Serta 
Penerapan Hukumnya. Jakarta: Prenada Media Group, 2018.

Samels, Max. Recent Changes to Merger Notification in Chilean Antitrust Law, International Immersion Program Papers, 2018.

Shiau, Daren and Elsa Chen. "ASEAN Developments in Merger Control." Journal of European Competition Law \& Practice 5, no. 3 (2014): 150.

Wardhana, I Nyoman Wisnu and Ahmad M. Ramli. "Harmonisasi Hukum Perusahaan Di ASEAN Sebagai Faktor Fundamental Dalam Implementasi Kegiatan Merger and Acquisition (M\&As).” Padjajaran Jurnal Ilmu Hukum 2, no. 2 (2015): 329. 